\title{
Herrn Prof. Dr. A. Brückner zum 70. Geburtstag
}

Die Unterzeíchneten freuen sích, Ihnen, sehr verehrter Herr Professor, zu Ihrem 70. Geburtstage ím Namen zahlreícher Fach-genossen, ehemalíger und jetzíger Schüler, die herzlíchsten Glückwünsche übermitteln zu können und bitten Sie, diese Festschrift als Zeichen íhrer Zuneigung und ihres Dankes entgegennehmen zu wollen.

Die Beíträge von Fachgenossen und Schülern aus aller Welt mögen Ihnen beiveisen, wie sehr Ihre jahrzehntelange Tätigkeit ím Inteiesse unseres Faches und vor allem auch Ihre unermüdliche Arbeit als Redaktor der «Ophthalmologíca» allgemeíne Hoch-schätzung erfahren haben. Zugleích entbieten wír Ihnen die besten Wünsche für Ihr wei-teres Wohlergehen.

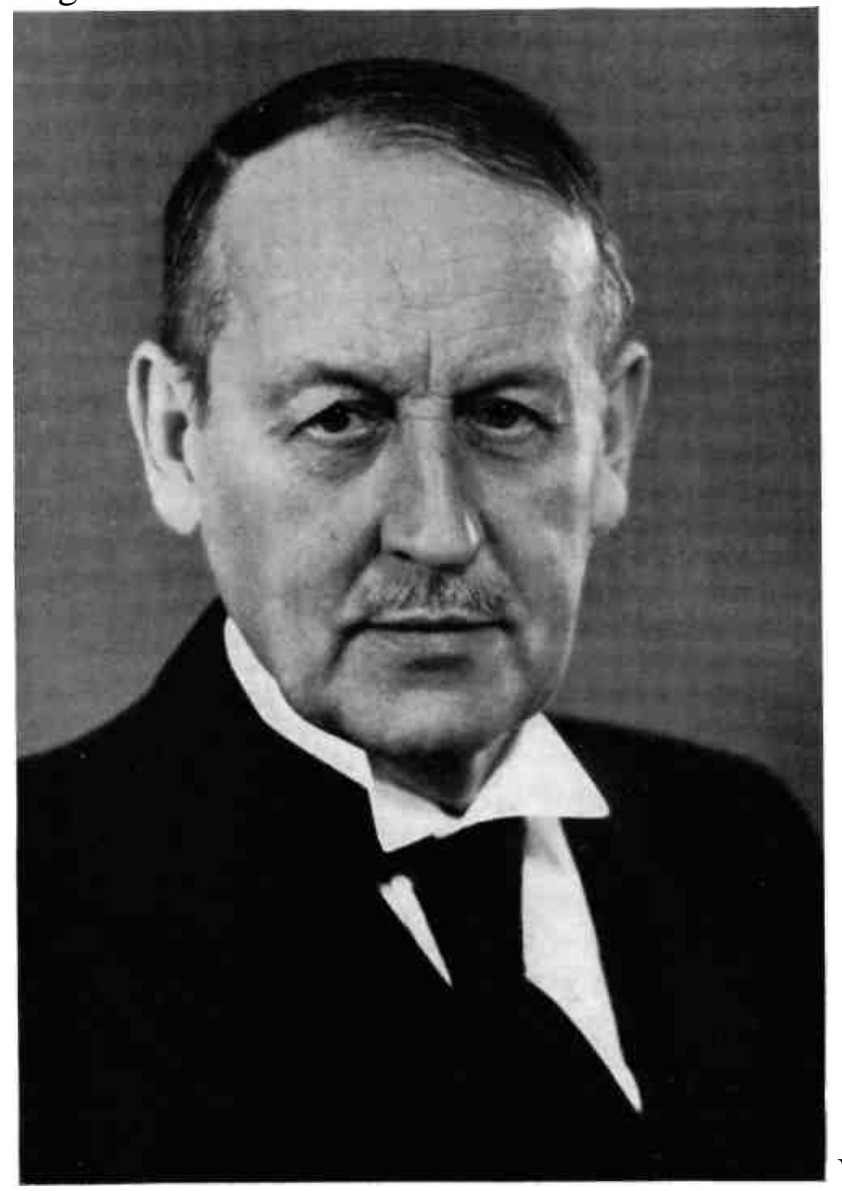

H. Weve (Utrecht)

V.S. Verlagsbuchhandlung S. Karger A.-G. 